\title{
Long-term nitrate and phosphate loading of river water in the Upper Manyame Catchment, Zimbabwe
}

\author{
J Nyamangara ${ }^{1 *}$, N Jeke ${ }^{2}$ and J Rurinda ${ }^{2}$ \\ 'International Crops Research Institute for the Semi-Arid Areas, Matopos Research Station, P.O. Box 776, Bulawayo, Zimbabwe \\ ${ }^{2}$ Department of Soil Science and Agricultural Engineering, University of Zimbabwe, P.O. Box MP167, Mount Pleasant, Harare, Zimbabwe
}

\section{ABSTRACT}

Urbanisation and agriculture represent a dramatic example of human interference in catchment hydrology. The impact of agricultural, domestic, industrial and municipal activities on river flow and water quality within the Upper Manyame Catchment Area (UMCA) was assessed using 7-year nitrate, phosphate and water flow rate data, collected by the Environmental Management Agency (EMA). Water samples for nitrate and phosphate analysis were collected at 8 points along the Manyame ( 2 points), Marimba ( 2 points) and Mukuvisi (4 points) rivers, and runoff volume was recorded at the mouth of each river. Annual runoff of each river was closely related to rainfall amount, with the lowest runoff being recorded during drought years. High nitrate and phosphate concentrations were recorded directly downstream of residential, municipal and industrial areas suggesting that these were the major sources of the pollutants found in the river water. For example, phosphate concentration at 2 sites along Mukuvisi River (downstream of domestic and industrial areas) exceeded the statutory limit $(0.5 \mathrm{mg} / \ell)$ for 'safe' or good quality water ('blue' category) according to the Zimbabwe Water (Waste and Effluent Disposal) Regulations, and ranged from $0.78 \mathrm{mg} / \ell$ during the dry season to $2.23 \mathrm{mg} / \ell$ during the wet season. In the Marimba River phosphate concentration at Site 4 (downstream of domestic, industrial and sewage processing plant) also exceeded the safe water quality standard by 4-6 times. Although Marimba River contributes the lowest proportion of runoff (relative to the other two rivers sampled) entering Lake Chivero, it contributed the highest nitrate (114 840 $\mathrm{kg} / \mathrm{yr}$ ) and phosphate (84 $324 \mathrm{~kg} / \mathrm{yr}$ ) loading. It was concluded that anthropogenic activities within the UMCA were the major sources of nitrate and phosphate pollution in the three rivers and pose a serious threat to the ecological sustainability of the rivers and lakes downstream, and to the economic wellbeing of nearby cities which rely on the water for potable uses.

Keywords: effluent, nutrient load, river water flow rate, urban agriculture, water pollution

\section{INTRODUCTION}

Increasing loads of nitrogen $(\mathrm{N})$ and phosphorus $(\mathrm{P})$ in water bodies has become one of the major environmental problems facing the world (Howarth et al., 1996; Seitzinger et al., 2010). A worldwide assessment (946 rivers) showed that, although most rivers displayed nitrogen export profiles ( $\mathrm{N}$ fraction distributions) reflecting pristine conditions, nitrate export to rivers that passed through human settlements was related to human population density (Alvarez-Cobelas et al., 2008). Although P discharges into coastal waters have stabilised or reduced in Western Europe, after unprecedented contamination during the second half of the $20^{\text {th }}$ century, $\mathrm{N}$ trends have not attenuated and are still increasing in some places (Thieu et al., 2010). In the Tibetan Plateau, which is the water source for $40 \%$ of the world's population, anthropogenic impacts (addition of metal and non-metal ions, including ammonium ions from mining and untreated municipal wastewater) on river water quality have been recorded in some locations in the Mekong River and Yarlung Tsangpo basins (Huang et al., 2009). In subSaharan Africa (SSA), most rivers that pass through municipal, industrial, mining, domestic and agricultural areas are polluted and pose an environmental concern (Nyamangara et al., 2008; Arimoro, 2009; Emeka et al., 2009). The concentration

To whom all correspondence should be addressed.

䀅 +263772 $234965 /+263712617063$; fax: $+263(0) 3838253$ or 8307; e-mail: j.nyamangara@cgiar.org

Received 7 November 2012; accepted in revised form 19 September 2013. of pollutants in river water is exacerbated by weak institutions that fail to effectively regulate and enforce safe disposal of wastewater and other pollutants (Nhapi, 2009).

Urban and peri-urban agriculture is also a major nonpoint source of water pollution. Non-point sources of pollution are challenging to control because they derive from activities which vary in space and time. For example, during the 2008/09 cropping season $50 \%$ of households in Harare, the capital city of Zimbabwe, grew maize to support their food requirements (Zimbabwe Vulnerability Assessment Committee, 2009). The increase in the number of people that have been growing crops inevitably results in increased use of $\mathrm{N}$ and $\mathrm{P}$ fertilisers. Some of the fertiliser remains in the top soil (e.g. P) where it can be washed away by runoff water, and some (e.g. N) leaches into groundwater. Besides causing environmental damage, loss of $\mathrm{N}$ and $\mathrm{P}$ from arable fields constitutes an economic loss to urban and peri-urban farmers, some of whom are very poor and live below the poverty datum line of 1 USD per day.

Most of the industrial activities in Zimbabwe, including agro-processing and fertiliser manufacture, are concentrated in Harare and its satellite towns. These urban settlements are located in the Upper Manyame Catchment Area (UMCA). Increased concentrations of pollutants that include nitrate and phosphate, have been reported in rivers that drain the UMCA (Mapanda, 2003; Nhapi et al., 2004; Nyamangara et al., 2008). Nutrients in river water cause a plethora of problems such as proliferation of algae and water hyacinth (Eichhornia crassipes), fish kills due to loss of oxygen, reduction of biological diversity, difficulties in potable water treatment, and clogging of irrigation pipes. For instance, periodic fish kills in the rivers 
that drain into Lake Chivero, and in the lake itself, have been blamed on excessive loading of nutrients ( $\mathrm{N}$ and $\mathrm{P}$ ) from industrial and municipal wastewaters in Harare and Chitungwiza (Moyo, 1997; Gratwicke et al., 2003). However, these nutrient loads have not been quantified over time.

Earlier attempts to measure $\mathrm{N}$ and $\mathrm{P}$ in rivers in Zimbabwe have generally reported as concentration values measured over a short period of time, usually a few months (e.g. Mathuthu et al., 1993; Dube et al., 2010). Nhapi et al. (2004) calculated the $\mathrm{N}$ and $\mathrm{P}$ loading into Lake Chivero using short-term data. Although data and information generated from short-term research may give insights, there is also a need to capture variation over a long period of time, which is necessary for informed decision making and planning for pollutant management. Vollenweider (1992) argued that it is not the concentration that matters, but the nutrient supply rate. A short-term exposure to a relatively high concentration of a pollutant may be less harmful than a prolonged exposure to a lower concentration (Miller et al., 2007). Pollution loading studies recognise that toxic effects are a function of both the magnitude of pollutant concentration and exposure time to that concentration (Adán et al., 1996). The objective of this study was to determine the long-term nitrate and phosphate concentration and loading in Manyame, Marimba and Mukuvisi rivers, which are the major streams draining the UMCA, and which feed into Lake Chivero in north-eastern Zimbabwe.

\section{MATERIALS AND METHODS}

\section{Site description}

The UMCA is drained by the Manyame, Marimba and Mukuvisi rivers, and the rivers in turn drain into Lake Chivero (Fig. 1). The lake is the major source of potable water for the City of Harare and its satellite towns of Chitungwiza, Epworth, Norton and Ruwa, which account for $47 \%$ of the urban population of Zimbabwe (Hranova et al., 2002). With the exception of Norton, these towns are located in the UMCA, thereby contributing to eutrophication problems in the rivers and Lake Chivero (Moyo, 1997). The National Water Quality Laboratory of the Environmental Management Authority (EMA) of Zimbabwe has established sampling points along the three rivers (Fig. 2) where water samples are regularly collected and analysed as part of long-term water quality monitoring.

The source of Manyame River is found $5 \mathrm{~km}$ west of Marondera town and the upstream catchment area comprises of commercial and communal farmlands. Thereafter, it flows through Chitungwiza, one of the most densely populated urban settlements in Zimbabwe, before it drains into Lake Chivero. The two sampling points used for the study were HCR21 (Site 1) (narrow bridge near Dema Growth Point, Seke Communal lands) and HCR 60 (Site 2) (Manyame River Bridge on the way to Masvingo) (Fig. 2).

Marimba River stretches for about $25 \mathrm{~km}$, originating from the University of Zimbabwe grounds in Harare. It flows through the northern and western parts of Harare's commercial centre, collecting surface runoff from low-, medium- and highdensity residential areas. It also flows through the Workington Industrial Area. The river passes through Crowborough Sewage Treatment Works (CSTW) and a farming area before discharging into Lake Chivero. Two sampling points used for the study were HCR52 (site 3) (Kambuzuma access through Warren Park D) and HCR51 (site 4) (downstream of Crowborough Sewage Works) (Fig. 2).

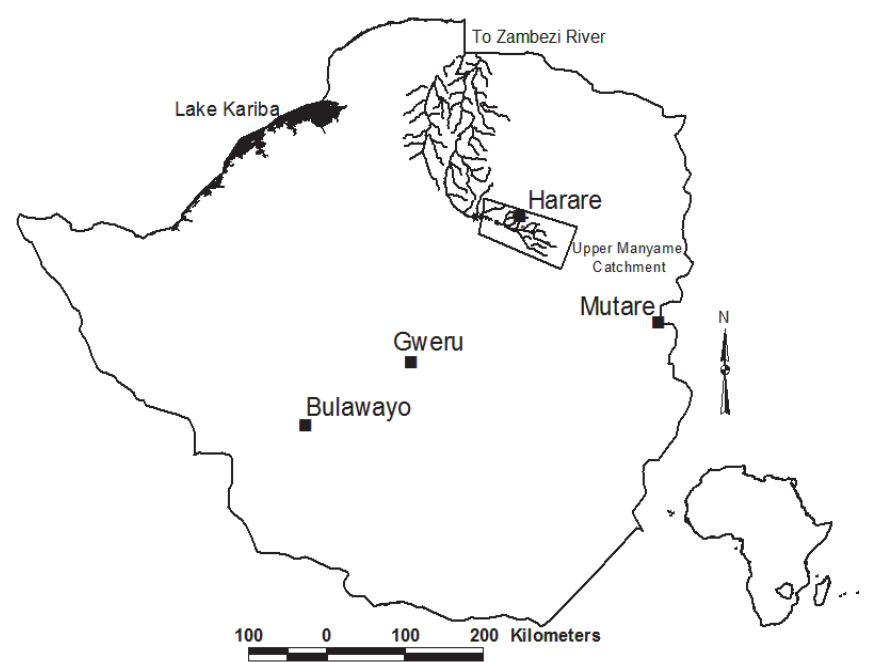

Figure 1

Map of Zimbabwe showing the location of Upper Manyame Catchment area

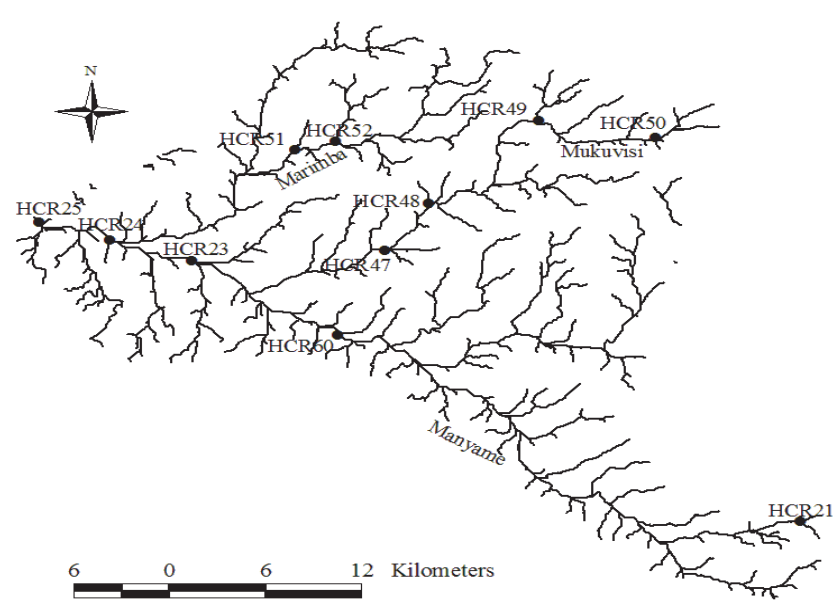

Figure 2

Map showing the water quality monitoring sampling points for the Upper Manyame Catchment Area (Zimbabwe) used in the study

Mukuvisi River drains the greater part of the City of Harare. The river passes through Msasa and Ardbennie industrial areas, and residential areas of Mbare, Parktown, Houghton Park, Waterfalls, Highfield and Glen Norah. The river also receives effluent from Southerton industrial area via a canal just below the bridge along Simon Mazorodze Road in Waterfalls. The four sampling points used for the study were: HCR50 (Site 5, next to Zimphos turn-off, on bridge), HCR49 (Site 6, on bridge behind OKMart in Braeside), HCR48 (Site 7, on bridge near Lord Malvern Shopping Centre) and HCR47 (Site 8, Glen Norah C roundabout from Chitungwiza) (Fig. 2).

Water samples were also collected after the convergence of the rivers, i.e., HCR 23 (Site 9) (just after the confluence of Mukuvisi and Manyame rivers), HCR 24 (Site 10) (just after all three rivers converge) and HCR 25 (Site 11) (just before discharge into Lake Chivero) (Fig. 2). The water flow rate and concentration of nitrate and phosphate in the water were also measured at the mouth of each river. 


\section{Water sampling and analysis}

Data sets for long-term (2001-2007) flow, nitrate and phosphate concentrations were obtained from EMA. The frequency of water sampling at each site was at least once per month but was not always the same for all sites. Nevertheless, the resulting database represents an unusually comprehensive and fairly regular dataset in space and time. Data for flow rate, nitrate and phosphate concentration at the mouth of each river (before they converged) was also collected for the same period. Nitrate concentration was determined by direct colorimetric method and phosphate concentration by colorimetric, stannous chloride method (APHA, 1995). The nitrate and phosphate loading in each river was calculated by multiplying nitrate and phosphate concentrations with the annual runoff recorded at the mouth of each river (Webb and Walling, 1985).

\section{Data analysis}

Concentration and stream flow data were divided into wet (November-May) and dry (June-October) seasons, and average concentrations computed. Nitrate and phosphate concentrations were compared to the Zimbabwe Water (Waste and Effluent Disposal) Regulations 2000 (blue category: $\leq 3 \mathrm{mg} / \ell$ $\mathrm{NO}_{3}^{-}, \leq 0.5 \mathrm{mg} / \ell$ phosphate) (Dube et al., 2010). The blue category denotes 'safe' water or good water quality.

\section{RESULTS}

\section{Long-term flow rates}

The long-term flow rate in each river peaked in the middle of the rainy season (January-March) and was highest for Manyame ( $>45000 \mathrm{~m}^{3} / \mathrm{s}$ ); flow rates for Marimba and Mukuvisi were similar to each other $\left(>5000 \mathrm{~m}^{3} / \mathrm{s}\right)$. However annual flow rate was highly variable, especially for Manyame River (Fig. 3), an indication of the variable nature of rainfall in the subSaharan region where severe droughts tend to occur once in every 9 to 10 years (Rockström, 2004).

\section{Nitrate and phosphate concentrations}

Nitrate and phosphate concentrations were compared with the threshold limits for safe water (blue category) according to the Zimbabwe Waste (Waste and Effluent Disposal) regulations of 2000 (Dube et al., 2010). In Manyame River, both nitrate and phosphate concentrations were below the statutory limit concentrations (Fig. 4). However nitrate concentration at the two sampled sites was more than double during the wet season than to the dry season, even though dilution from rainwater was expected to lower the concentration of nitrates in the river during the high rainfall period.

For Marimba River, nitrate concentrations at both Site 3 and Site 4 were higher in the wet season compared to the dry season (Fig. 5). At Site 4 the nitrate concentration was above the statutory limit concentration during the wet season (Fig. 5). However phosphate was higher during the dry season, and was above the statutory limit concentration for both seasons at Site 4 . The massive increase in nitrate and phosphate concentrations from Site 3 to Site 4 (Fig. 5) implies that a major source of water pollution occurs between the sites. Both sites were located within a domestic and heavy industrial zone but Site 4 was located downstream of a point where treated sewage effluent from Crowborough Sewage Processing Plant,

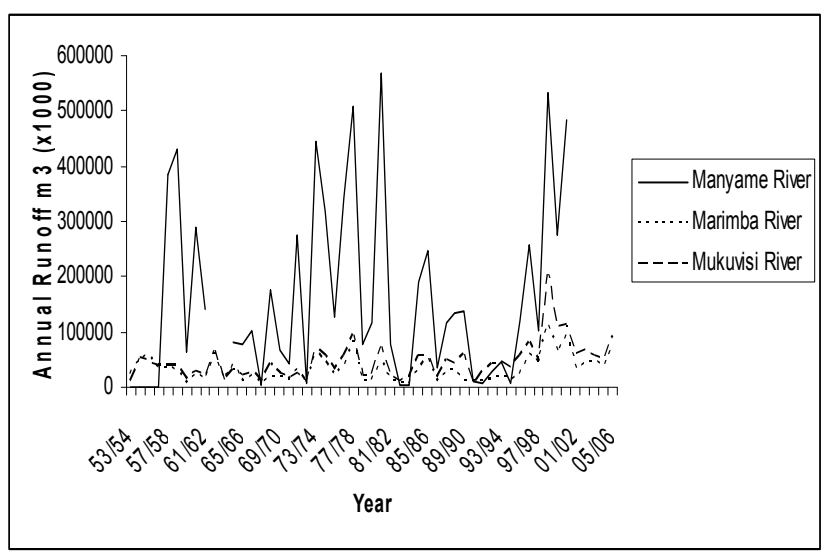

Figure 3

Variation in annual water flow rate at the mouths of Manyame, Marimba and Mukuvisi rivers, upstream of Lake Chivero, Zimbabwe, over a 53-year period
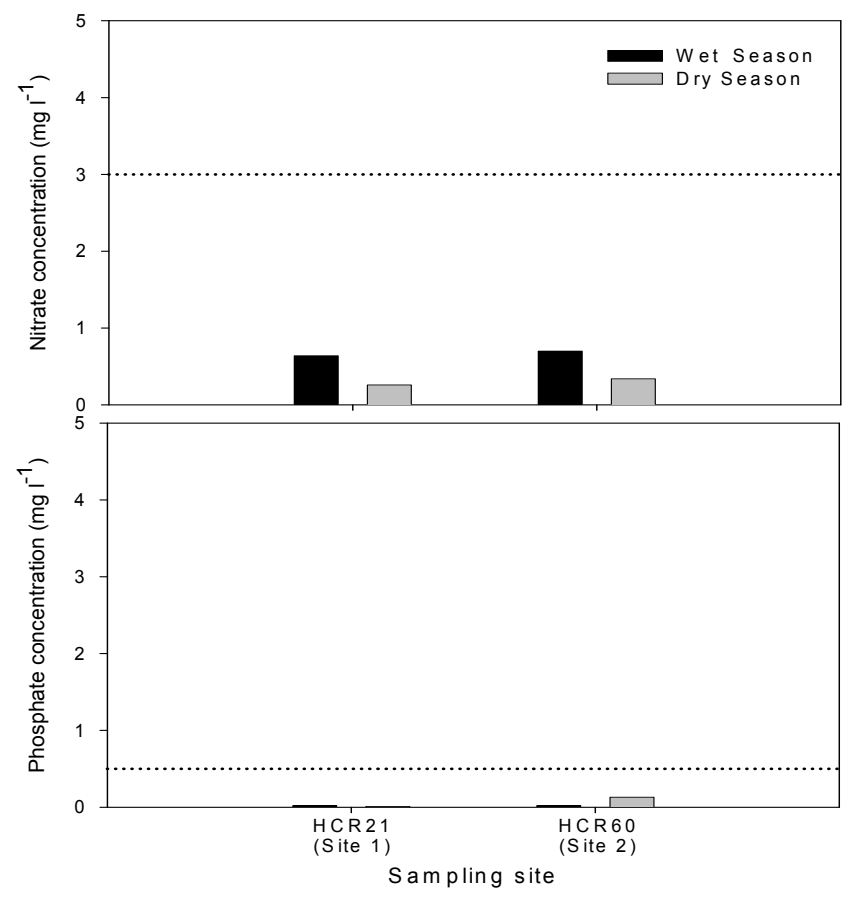

Figure 4

Mean concentration of nitrate $\left(\mathrm{NO}_{3}^{-}\right)$and phosphate $\left(\mathrm{PO}_{4}^{-}\right)$along Manyame River over a 7-year period (2001-2007). HCR 21 (Site 1) on a narrow bridge near Dema Growth Point, Goromonzi District, and HCR69 (Site 2) - on bridge along Masvingo Highway

the main plant serving the western area of Harare, enters the stream (Fig. 2).

Along Mukuvisi River, both nitrate and phosphate concentrations were higher during the wet season and nitrate concentrations at all sites were below the statutory threshold limit (Fig. 6). Phosphate concentration was also higher during the wet season and at Site 7 and 8 was substantially above the statutory threshold limit, suggesting a major source of the chemical between Site 6, which had trace amounts $(<0.25 \mathrm{mg} / \ell)$, and Site 7 (Fig. 6). One of the major tributaries of Mukuvisi River originates near Msasa industrial area and Epworth residential area, and flows through Hatfield and Prospect residential areas before joining the main river between Sites 6 and 7 . 


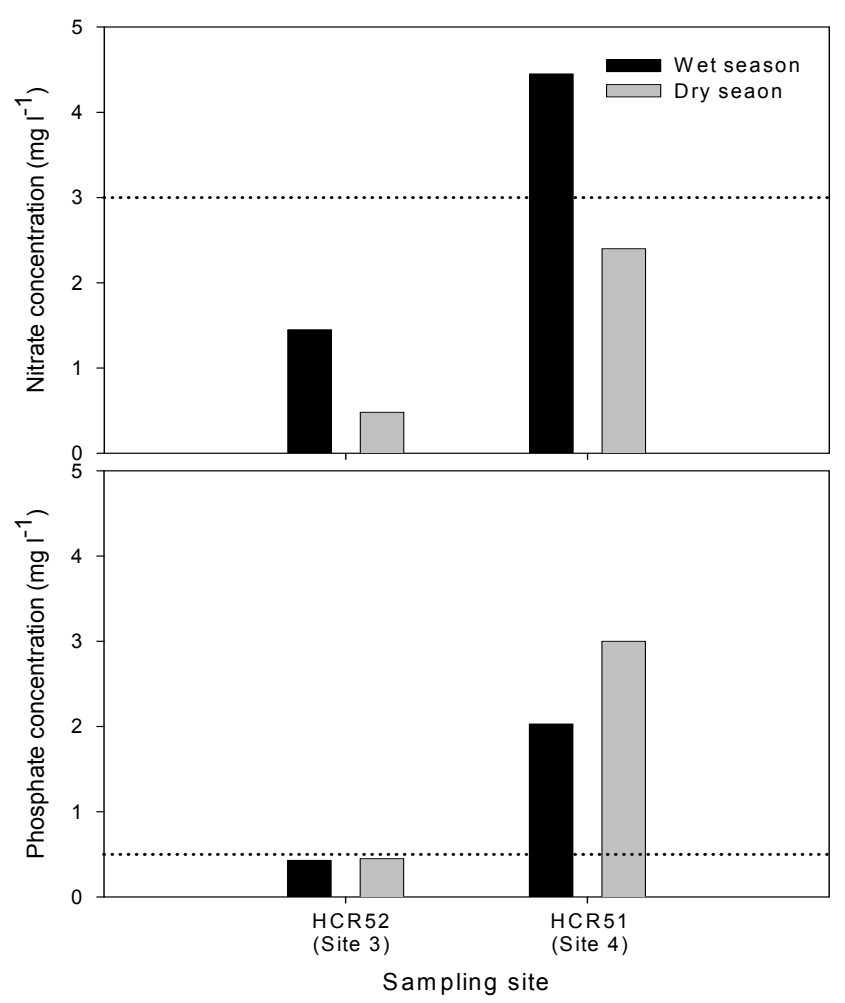

Figure 5

Mean concentration of nitrate $\left(\mathrm{NO}_{3}^{-}\right)$and phosphate $\left(\mathrm{PO}_{4}^{-}\right)$along Marimba River over a 7-year period (2001-2007). HCR 52 (Site 3) - Kambuzuma Access through Warren Park D, and HCR 51 (Site 4) Caravan Park through Amalinda Road); all sites in Harare.

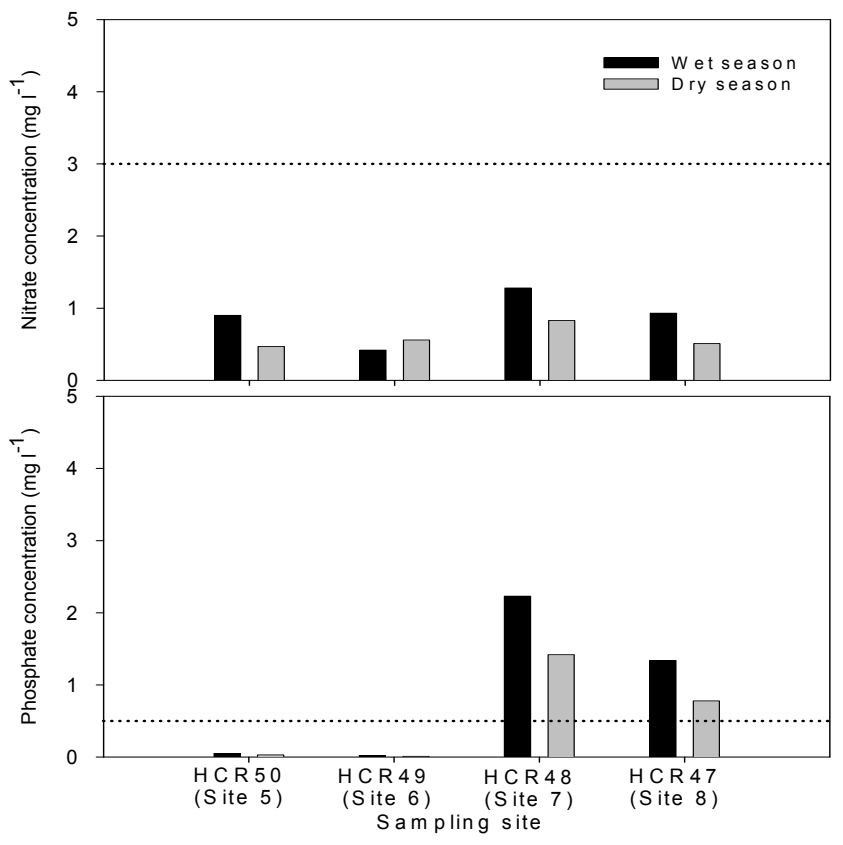

Figure 6

Mean concentration of nitrate $\left(\mathrm{NO}_{3}^{-}\right)$and phosphate $\left(\mathrm{PO}_{4}^{-}\right)$along Mukuvisi River over a 7-year period (2001-2007). HCR50 (Site 5) - on bridge just before ZIMPHOS turn-off in Msasa, HCR49 (Site 6) - on bridge behind OKMart in Baeside, HCR 48 (Site 7) - on bridge just before Lord Malvern Shopping Centre, and HCR24 (Site 8) - on bridge near Glen Norah C roundabout from Chitungwiza; all sites in Harare.
TABLE 1

Average annual water discharge, and nitrate and phosphate load, at the mouths of Marimba, Mukuvisi and Manyame rivers in the Upper Manyame Catchment Area

\begin{tabular}{|l|c|c|c|}
\hline River & $\begin{array}{c}\text { Discharge }^{\ddagger} \\
\left(\mathbf{m}^{3} / \mathbf{y r}\right)\end{array}$ & $\begin{array}{c}\text { Nitrate } \\
(\mathbf{k g} / \mathbf{y r})\end{array}$ & $\begin{array}{c}\text { Phosphate } \\
(\mathbf{k g} / \mathbf{y r})\end{array}$ \\
\hline Manyame & 177826000 & 92470 & 13337 \\
\hline Marimba & 33530000 & 114840 & 84324 \\
\hline Mukuvisi & 46071000 & 33171 & 48835 \\
\hline Total & 257427000 & 240481 & 146500 \\
\hline
\end{tabular}

${ }^{*}$ River water volume averaged over 53 years, $\mathrm{NO}_{3}-$ and $\mathrm{PO}_{4-}^{3-}$ averaged over 7 years (2001-2007)

\section{Nitrate and phosphate loading}

Manyame River contributed $69.1 \%$ of the total runoff measured, followed by Mukuvisi River (17.9\%) (Table 1). Although Marimba River accounted for the lowest contribution of runoff to Lake Chivero, it contributed the highest nitrate $(47.8 \%)$ and phosphate $(57.6 \%)$ loading (Table 1 ) and is therefore a major source of pollution and eutrophication to the lake (Moyo, 1997). Marimba and Manyame (38.5\%) rivers contributed $83.6 \%$ of nitrate loading while Marimba and Mukuvisi (33.3\%) rivers contributed $90.9 \%$ of the phosphate imported into Lake Chivero (Table 1).

\section{DISCUSSION}

Variation in nitrate and phosphate concentration along a river assists in the identification of zones of intense pollution where detailed monitoring can be conducted. The low nitrate and phosphate concentrations at Site 1 along Manyame River (upstream of Chitungwiza town) indicated the low loading from the commercial and smallholder farming areas, both livestock and cropping areas, upstream of the site. However, the relatively high nitrate and phosphate concentrations at sampling points located within domestic and industrial areas, and soon after sewage processing plants, indicated that these were the major sources of nitrate and phosphate pollution in the river water in the UMCA. In a related study by Nyamangara et al. (2008), it was concluded that elevated heavy metal concentrations in water and sediments along Mukuvisi River originated from industrial and residential areas of Harare.

The high nitrate and phosphate concentrations in water from the three rivers during the wet season, with the exception of phosphate in Marimba River (Fig. 4), was not expected. Generally the increased river water volume during the wet season has a dilution effect on pollutant levels (e.g. Emeka et al., 2009). However, these findings were supported by Barco et al. (2008), who reported increased nitrate concentration during the wet season in the upper Arroyo Seco watershed in California, USA, particularly after the occurrence of storms preceded by dry periods. In our study, the higher nitrate and phosphate concentrations in the river water were attributed to uncollected domestic solid waste and sewage sludge from burst pipes that accumulate during the dry season and are then washed into the rivers during the rainy season. Economic challenges in Zimbabwe since the year 2000 have resulted in municipalities failing to maintain sewerage infrastructure and the collection of solid waste (Tibaijuka, 2005). Therefore sewage sludge and effluent, and solid waste that accumulated in open 
spaces, were washed into rivers during the rainy season. Nhapi (2009) also reported that runoff from cropped fields in the UMCA was an important source of $\mathrm{N}$ and $\mathrm{P}$ washed into Lake Chivero. Urban and peri-urban agriculture, often in ecologically sensitive areas and using high fertiliser application rates (e.g. Mapanda, 2003), has rapidly increased in Harare and its satellite towns within UMCA, as poor households seek to supplement their meagre incomes.

Nitrate and phosphate concentrations at Site 4 on the Marimba River, and phosphate concentrations at Sites 7 and 8, were above the threshold limits for river water in Zimbabwe (Dube et al. 2010) and therefore pose an environmental and health risk to aquatic life and the urban population of Harare and satellite towns, respectively. The high phosphate concentrations in the Marimba and Mukuvisi rivers is a major cause for concern as $\mathrm{P}$ is generally the most limiting nutrient to growth of aquatic vegetation under natural conditions in most freshwater bodies. The resulting algal blooms and other aquatic plants which flourish with increased $\mathrm{P}$ availability make water purification difficult, impart an unpleasant taste and odour to drinking water (Marshall, 1997) and have been blamed for periodic fish kills in Lake Chivero (Moyo, 1997).

\section{CONCLUSION}

Anthropogenic activities within Harare and its satellite urban centres are contributing significant amounts of nitrate and phosphate to rivers within the Upper Manyame Catchment Area which drain into Lake Chivero, the main source of potable water for the cities, thereby posing both an ecological and socio-economic concern. The concentration of ions, particularly nitrates, in the water was higher during the wet season due to waste washed into the rivers by runoff from urban settlements. Although Marimba River accounted for the lowest volume of water flowing into Lake Chivero, it contributed the highest nitrate and phosphate loading. There is a need for more detailed investigations near the identified pollution 'hotspots' to identify the specific sources so that corrective measures can be taken.

\section{ACKNOWLEDGEMENTS}

The authors thank the Water Quality Section of the Zimbabwe Environmental Management Agency and the Zimbabwe National Water Authority for providing long-term data on river water flow and nitrate and phosphate concentrations in the river water.

\section{REFERENCES}

ADÁN A, ESTAL PD, BUDIA F, GONZÁLEZ M and VIÑUELA E (1996) Laboratory evaluation of the novel naturally derived compound spinosad against ceratitiscapitata. Pestic. Sci. 48 261-268.

APHA (AMERICAN PUBLIC HEALTH ASSOCIATION) (1995) Standard Methods for the Examination of Water and Wastewater (19 ${ }^{\text {th }}$ edn.). American Public Health Association, American Water Works Association, and Water Pollution Control Federation, Washington D.C.

ALVAREZ-COBELAS M, ANGELER DG and SANCHEZ-CARRILLO S (2008) Export of nitrogen from catchments: A worldwide analysis. Environ. Pollut. 156 261-269.

ARIMORO FO (2009) Impact of rubber effluent discharges on the water quality and macroinvertebrate community assemblages in a forest stream in the Niger Delta. Chemosphere 77 440-449.
BARCO J, HOGUE TS, CURTO V and RADEMACHER L (2008) Linking hydrology and stream geochemistry in urban fringe watersheds. J. Hydrol. 360 31-47.

DUBE T, MAKAKA C and SIBANDA Z (2010) An assessment of the effect of industrial and sewage effluent on aquatic invertebrates: A case study of a southern urban stream, Zimbabwe. J. Sustain. Dev. 3 210-214.

EMEKA UJ, BRAIDE SA and CHINDAH AC (2009) Impact of abattoir wastes based on some physicochemical parameters on Woji Creek, Port Harcourt, Nigeria. Manage. Environ. Qual. 20 581-591.

GRATWICKE B, MARSHALL BE and NHIWATIWA T (2003) The distribution and relative abundance of stream fishes in the upper Manyame River, Zimbabwe, in relation to land use, pollution and exotic predators. Afr. J. Aquat. Sci. 28 25-34.

HOWARTH RW, BILLEN G, SWANEY D, TOWNSEND A, JAWORSKI N, LAJTHA K, JDOWNING A, ELMGREN R, CARACO N, JORDAN T, BERENDSE F, FRENEY J, KUDEYAROV V, MURDOCH P and ZHU ZL (1996) Regional nitrogen budgets and riverine $\mathrm{N} \& \mathrm{P}$ fluxes for the drainages to the North Atlantic Ocean: Natural and human influences. Biogeochemistry 35 75-139.

HRANOVA R, GUMBO B, KLEIN J and VAN DER ZAAG P (2002) Aspects of the water resources management practice with emphasis on nutrients control in the Chivero Basin, Zimbabwe. Phys. Chem. Earth 27 875-885.

HUANG X, SILLANPAA M, GJESSING ET and VOGT RD (2009) Water quality in the Tibetan Plateau: Major ions and trace elements in the headwaters of four major Asian rivers. Environment 40 (7) 6242-6254.

MAPANDA F (2003) Environmental effects of wastewater quality and management, on soil and horticultural production in Harare. M.Phil., University of Zimbabwe. 112 pp.

MARSHALL BE (1997) Lake Chivero after forty years: The impact of eutrophication. In: NAG Moyo (ed.) Lake Chivero: A Polluted Lake. University of Zimbabwe Publications, Harare.

MATHUTHU AS, ZARANYIKA FM and JONNALAGADDA SB (1993) Monitoring of water quality in upper Mukuvisi River in Harare, Zimbabwe. Environ. Int. 19 51-61.

MILLER KA, SISCOVICK AS, SHEPPARD L, SHEPHERD K, SULLIVAN JH, ANDERSON GL and KAUFMAN JD (2007) Long-term exposure to air pollution and incidence of cardiovascular events in women. N. Engl. J. Med. 356 447-458.

MOYO NAG (1997) Causes of massive fish deaths in Lake Chivero. In: NAG Moyo (ed.) Lake Chivero: A Polluted Lake. University of Zimbabwe Publications, Harare.

NHAPI I (2009) The water situation in Harare, Zimbabwe: A policy and management problem. Water Polic. 11 221-235.

NHAPI I, SIEBEL MA and GIJZEN HJ (2004) The impact of urbanisation on the water quality of Lake Chivero, Zimbabwe. Water Environ. J. 18 44-49.

NYAMANGARA J, BANGIRA C, TARUVINGA T, MASONA C, NYEMBA A and NDLOVU D (2008) Effects of sewage and industrial effluent on the concentration of $\mathrm{Zn}, \mathrm{Cu}, \mathrm{Pb}$ and $\mathrm{Cd}$ in water and sediments along Waterfalls stream and lower Mukuvisi River in Harare, Zimbabwe. Phys. Chem. Earth 33 708-713.

ROCKSTRÖM J (2004) Making the best of climatic variability: options for upgrading rainfed farming in water scarce regions. Water Sci. Technol. 49 (7) 151-156.

SEITZINGER SP, MAYORGA E, BOUWMAN AF, KROEZE C, BEUSEN AHW, BILLEN G, VAN DRECHT G, DUMONT E, FEKETE BM, GARNIER J and HARRISON JA (2010) Global river nutrient export: A scenario analysis of past and future trends. Global Biogeochem. Cycles 24:GB0A08.

THIEU V, GARNIER J and BILLEN G (2010) Assessing the effect of nutrient mitigation measures in the watersheds of the Southern Bight of the North Sea. Sci. Total Environ. 408 1245-1255.

TIBAIJUKA AK (2005) Report of the fact-finding mission to Zimbabwe to assess the scope and impact of Operation Murambatsvina by the UN Special Envoy on Human Settlements Issues in Zimbabwe. United Nations, New York. 100 pp. 
VOLLENWEIDER RA (1992) Coastal marine eutrophication principles and control. Sci. Total Environ., Suppl. 1992: Marine Coastal Eutrophication 1-20.

WEBB BW and WALLING DE (1985) Nitrate behaviour in stream flow from a grassland catchment in Devon, U.K. Water Res. 19 1005-1016.
ZIMBABWE VULNERABILITY ASSESSMENT COMMITTEE

(ZIMVAC) (2009) Urban Food Security Assessment. Scientific Industrial Research and Development Centre (SIRDC) and Food and Nutrition Council (FNC), Harare. 30 pp. 